Boletín de la Sociedad Geológica Mexicana

VOLUMEN 65, NÚM. 2, 2013, P. 207-211

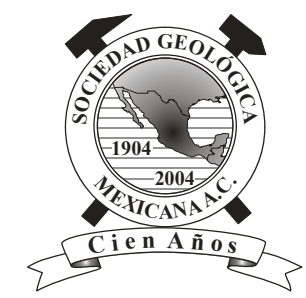

\title{
Enoploclytia tepeyacensis n. sp. (Crustacea, Decapoda, Erymidae) from the Cretaceous (Campanian) of Coahuila, NE Mexico
}

\author{
Francisco J. Vega ${ }^{1, *}$, Alessandro Garassino², Régulo Zapata Jaime ${ }^{3}$ \\ ${ }^{1}$ Instituto de Geología, Universidad Nacional Autónoma de México, Ciudad Universitaria, Coyoacán, 04510 México, D.F. \\ ${ }^{2}$ Museo di Storia Naturale, Sezione di Paleontologia, Corso Venezia 55, I-20121 Milán, Italia. \\ ${ }^{3}$ Riva Palacio 270, zona centro, 26700 Sabinas Coahuila, México. \\ *vegver@unam.mx
}

\begin{abstract}
The erymid lobster Enoploclytia tepeyacensis n. sp., is reported for the first time in the early Campanian beds of the Austin Group (Dessau Chalk) near Jiménez, Coahuila, NE Mexico. The new species represents the most complete record of Enoploclytia in North and Central America. The third report of Enoploclytia in Mexico is documented.
\end{abstract}

Keywords: Crustacea, Decapoda, Erymidae, Campanian, Cretaceous, Mexico.

Resumen

La langosta erímida Enoploclytia tepeyacensis $n$. sp. se reporta por vez primera en las capas del Campaniano inferior del Grupo Austin (Dessau Chalk) en las inmediaciones de Jiménez, Coahuila, NE de México. La nueva especie representa el registro más completo de Enoploclytia en América del Norte y América Central. Se documenta el tercer reporte de especies del género Enoploclytia en México.

Palabras Clave: Crustacea, Decapoda, Erymidae, Campaniano, Cretácico, México.

\section{Introduction and geological setting}

Rocks of the Dessau Formation (Campanian, Austin Group) crop out near Jiménez, Coahuila, NE Mexico (Figure 1). The Dessau Formation has an approximate thickness of $30 \mathrm{~m}$ in the study area, where invertebrate fossils including ammonoids and echinoids are found in association with the arthropod described here. Several reports deal with the stratigraphy of the Dessau Formation (Stephenson, 1936; Young and Marks, 1952; Young, 1963; Young and Woodruff, 1985; Lundquist, 2000; Cobban et al., 2008; among others). Housh (2007) wrote, "The Dessau Chalk is a white chalk characterized by a Phrygia aucella
(Roemer, 1849) biostrome. The lower portion, up to the Phrygia aucella layer comprises the "Gryphaea" aucella zone of Young and Marks (1952); the overlying Exogyra leviuscula zone comprises the upper portion. The Dessau Chalk has a thickness of approximately $29 \mathrm{~m}$ in the Austin area. The Dessau Chalk is discomformably overlain by the Burditt Marl Formation. Carrasco (1969) reported the large ammonoid Parapuzosia bosei Scott and Moore, 1928, from a locality nearby where the specimens here reported were found, along with Menavites (Menavites) internodosus (Renz, 1936) and M. (M.) desinodosus (Renz, 1936), and suggested an early Campanian age for the Dessau beds on this region. 

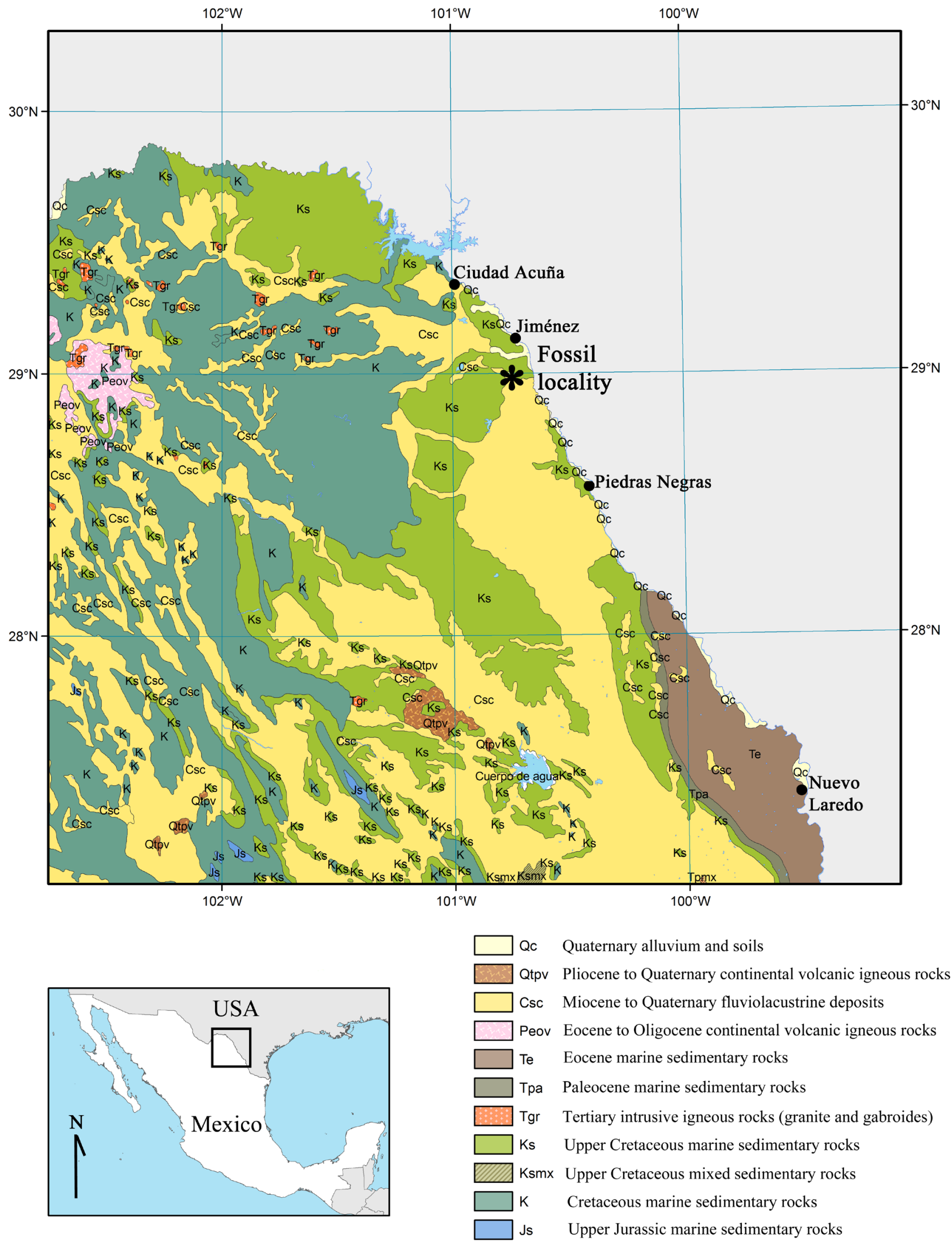

Figure 1. Geologic map of the fossil locality near Ejido El Tepeyac, Jiménez County, Coahuila. Modified from Servicio Geológico Mexicano. 


\section{Material}

Two specimens, three-dimensionally preserved, assigned to Enoploclytia tepeyacensis n. sp. (Erymidae Van Straelen, 1925), are deposited at the Museo de Múzquiz, Coahuila (MUZ).

The systematic arrangement used in this paper follows the recent classification proposed by Schweitzer et al. (2010), using the following abbreviations: hcxp: height of carapace; lcxp: length of carapace; wcxp: width of carapace.

\section{Systematic palaeontology}

Superfamily Erymoidea Van Straelen, 1925 Family Erymidae Van Straelen, 1925

Genus Enoploclytia McCoy, 1849

Type species Astacus leachii Mantell, 1822, by monotypy

Fossil species see Schweitzer et al. (2010)

Enoploclytia tepeyacensis $\mathrm{n}$. $\mathrm{sp}$.

Figure 2

\subsection{Diagnosis}

Carapace elongate and cylindrical; deep cervical groove, gently inclined, intercepting dorsal margin at an angle of $c a .60^{\circ}$; dorsal midline of the carapace without intercalated plate; deep, very reduced gastro-orbital groove; deep, sinuous postcervical groove, intercepting dorsal margin at an angle of $c a .50^{\circ}$; deep, very short branchiocardiac groove, not joining postcervical groove, not extending ventrally below mid-height, intercepting dorsal margin at an angle of $c a .60^{\circ}$; deep hepatic groove, strongly convex ventrally at intersection with postcervical groove and strongly concave dorsally at intersection with cervical groove; deep inferior groove strongly convex posteriorly; all regions of the carapace covered dorsally with strong tubercles, becoming reduced in size ventrally.

\subsection{Etymology}

The trivial name alludes to El Tepeyac area, where the Mexican specimens were discovered.

Holotype. MUZ-824.

Paratype. MUZ-825.

Type locality. Jiménez (Coahuila, NE Mexico).

Geological age. Campanian (Late Cretaceous).

\subsection{Material and measurements}

Two specimens from NE Mexico (Holotype MUZ-824 - lcxp: 96.8 mm; wcxp: $53.2 \mathrm{~mm}$; hcxp: $44.2 \mathrm{~mm}$; Paratype MUZ-825 - lcxp: $65.9 \mathrm{~mm}$; hcxp: $32.1 \mathrm{~mm}$ ).

\subsection{Description}

Carapace elongate, cylindrical, slightly inflated between grooves; front not visible; straight dorsal margin, with a row of small, anteriorly directed spines; dorsal midline of carapace without intercalated plate; rimmed posterior margin, strongly convex medially and ventrally; ventral margin strongly curved; deep cervical groove, gently inclined, intercepting dorsal margin at an angle of $c a .60^{\circ}$; deep, subtle gastro-orbital groove, intercepting cervical groove medially; weak, short, shallow antennal groove approaches but does not intercept anterior margin; deep, sinuous postcervical groove, intercepting dorsal margin at an angle of $c a .50^{\circ}$, strongly inclined, concave forward medially, intercepting inferior groove ventrally; deep, very short branchiocardiac groove, not joining postcervical groove, not extending ventrally below mid-height, intercepting dorsal margin at an angle of $c a .60^{\circ}$; deep hepatic groove, strongly convex ventrally in intersection with postcervical groove and strongly concave dorsally in intersection with cervical groove; slightly inflated adductor muscle insertion area; deep inferior groove strongly convex posteriorly; all regions of carapace covered dorsally with strong tubercles, reducing in size ventrally; some larger tubercles arranged randomly in antennal region.

\section{Discussion and Conclusions}

As reported by Förster (1966) and Schweitzer and Feldmann (2001), representatives of Enoploclytia McCoy, 1849 are usually confused with those of Palaeastacus Bell, 1850, and Eryma Von Meyer, 1840. However, there are some morphological distinctions among these genera in order to justify their systematic validity within the family, as pointed out by Förster (1966). Indeed, the postcervical and brachiocardiac grooves are closely spaced and do not extend to the dorsum in Eryma; postcervical and branchiocardiac grooves are closely spaced and the branchiocardiac groove does not extend ventrally below mid-height of the carapace in Enoploclytia; postcervical and branchiocardiac grooves are longer and typically extend below the midline of the carapace in Palaeastacus.

According to features described by Förster (1966), the Mexican specimens are assigned to Enoploclytia because the short branchiocardiac groove does not extend ventrally below mid-height of the carapace. As reported by Schweitzer et al. (2010), five species from the Early to Late Cretaceous are known to date from the United States: E. sculpta Rathbun, 1926, E. triglypta Stenzel, 1945, E. tumimanus Rathbun, 1935, E. wenoensis Rathbun, 1935, and E. wintoni Stenzel, 1945. Enoploclytia sculpta from the Maastrichtian (Late Cretaceous) of the Ripley Fm. (Tennessee, USA), known by only pleonal somites, probably does not belong to Enoploclytia because it lacks 


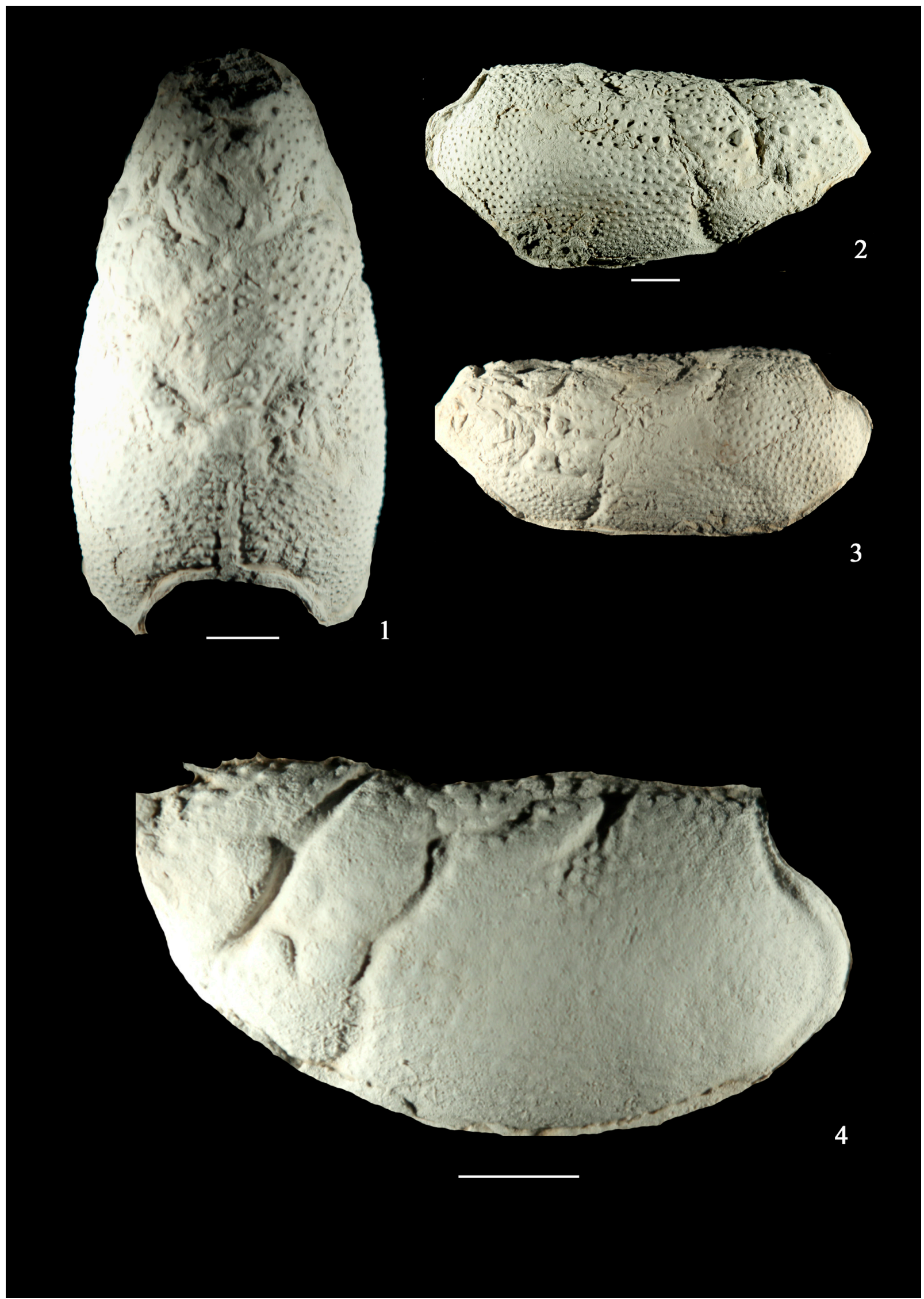

Figure 2. Enoploclytia tepeyacensis n. sp., early Campanian, upper Dessau Formation, Coahuila, Mexico (MUZ 825, 824). 1) Dorsal view of holotype MUZ$824 ; 2$ ) Right lateral view of holotype MUZ-824; 3) Left lateral view of holotype MUZ-824; Left lateral view of paratype MUZ-825. Scale bar=10 mm. 
strong spines on the pleon (Stenzel, 1945). Enoploclytia triglypta from the Late Cretaceous (Coniacian) of Fannin County (Texas, USA) should be assigned to Palaeastacus, according to Förster (1966), because the postcervical and branchiocardiac grooves are long and typically extend below the midline of the carapace. The holotype of Enoploclytia tumimanus (USNM 73799) from the Paleocene of the Sucarnnoochee Shale, Midway Group (Alabama, USA) (not the Selma Chalk, Late Cretaceous, according to Rathbun, 1935 ) is an incomplete carapace, partially preserving the grooves, which do not allow comparison with the Mexican specimens. Enoploclytia wenoensis from the Early Cretaceous (Albian) of Cooke County (Texas, USA), exhibit smooth, spineless abdominal somites, and probably does not belong to Enoploclytia, according to Stenzel (1945). Enoploclytia wintoni from the Early Cretaceous (Albian) of Tarrant County (Texas, USA) is known only from right and left chelipeds, which do not allow comparison with the Mexican specimens.

Based upon the above-mentioned observations, we can attest that Enoploclytia tepeyacensis n. sp. is the most complete record of Enoploclytia known to date in North and Central America. Enoploclytia tumimanus Rathbun (1935) was reported for the Maastrichtian Escondido Formation of Coahuila, Mexico. Based on a pair of long chelipeds, Vega et al. (2007) reported Enoploclytia gardnerae (Rathbun, 1935) from the Paleocene Rancho Nuevo Formation, Coahuila, Mexico. They also reported Enoploclytia sp. for a single, poorly preserved carapace from the same unit.

\section{Acknowledgements}

We are grateful with Laura Luna-González (Instituto de Geología, UNAM) for her kind support with maps and images. Héctor Porras-Múquiz provided support to house specimens at the Museo de Múzquiz, Coahuila, Mexico. José Ventura provided important references. Special thanks to Paleontólogos Aficionados de Sabinas (PASAC) and people of Jiménez, Coahuila, for their support during fieldwork. We thank Günter Schweigert, from the Staatliches Museum für Naturkunde, Stuttgart, Germany, and Rodney M. Feldmann, from the Geology Department at Kent State University, Ohio, USA, for careful review and criticism.

\section{References}

Bell, T., 1850, Notes on the Crustacea of the Chalk Formation, in Dixon, F. (ed.), The geology and fossils of the Tertiary and Cretaceous formations of Sussex: London, Brown, Green \& Longmans, 344-345.

Carrasco, B., 1969, Amonitas del Campaniano inferior del norte de Coahuila: Boletín de la Sociedad Geológica Mexicana, 30, 139-154.

Cobban, W.A., Hook, S.C., McKinney, K.C., 2008, Upper Cretaceous molluscan record along a transect from Virden, New Mexico, to Del Rio, Texas: New Mexico Geology, 30, 75-92.
Förster, R., 1966, Über die Erymiden, eine alte konservative Familie der mesozoischen Dekapoden: Palaeontographica, 125, 61-175.

Housh, T.B., 2007, Bedrock Geology of Round Rock and Surrounding Areas, Williamson and Travis Counties, Texas: Round Rock, Texas, Institution, $\mathrm{PhD}$ thesis, $65 \mathrm{p}$.

Lundquist, J.J., 2000, Foraminiferal biostratigraphic and paleoceanographic analysis of the Eagle Ford, Austin and Taylor Groups (Middle Cenomanian through lower Campanian) of Central Texas: Austin, Texas, The University of Texas, $\mathrm{PhD}$ thesis, $545 \mathrm{p}$.

Mantell, G.A., 1822, The fossils of the South Downs; or illustrations of the geology of Sussex: London, Lupton Relfe, $327 \mathrm{p}$.

McCoy, F., 1849, On the classification of some British fossil Crustacea with notices of new forms in the University Collection of Cambridge: Annals and Magazine of Natural History, series 2, 4, 161-179; 330-335.

Rathbun, M.J., 1926, Crustacea, in B. Wade (ed.), The fauna of the Ripley Formation of Coon Creek, Tennessee: United States Geological Survey, Professional Paper, 137, 184-191.

Rathbun, M.J., 1935, Fossil Crustacea of the Atlantic and Gulf Coastal Plain: Geological Society of America, Special Paper, 2, 1-160.

Renz, H.H., 1936, Neue Cephalopoden aus der oberen Kreide von Río Grande del Norte (Mexico und Texas), mit einer Einführung von Walter Staub: Abhandlungen der Schweizerischen Palaeontologischen Gesellschaft, 57, 1-16.

Roemer, F.A., 1849, Texas, mit besonderer Rücksicht auf deutsche Auswanderung und die physischen Verhaltnisse des Landes nach eigener Beobachtung geschildert von Dr. Ferdinand Roemer: A. Marcus, Bonn, 464 p. ?

Schweitzer, C.E., Feldmann R.M., 2001, New Cretaceous and Tertiary decapod crustaceans from western North America: Bulletin of the Mizunami Fossil Museum, 28, 173-210.

Schweitzer, C.E., Feldmann, R.M., Garassino, A., Karasawa, H., Schweigert, G., 2010, Systematic list of fossil decapod crustacean species: Crustaceana Monographs, 10, 1-222.

Scott, G., Moore, M., 1928, Ammonites of enormous size from the Texas Cretaceous: Journal of Paleontology, 2, 273-278.

Stenzel, H.B., 1945, Decapod crustaceans from the Cretaceous of Texas: The University of Texas Publication, 4401, 401-477.

Stephenson, L.W., 1936, Stratigraphic relations of the Austin, Taylor, and equivalent formations in Texas: United States Geological Survey, Professional Paper, 186-G, 133-146.

Van Straelen, V., 1925, Contribution à l'étude des Crustacés décapodes de la periode jurassique: Mémoirs de l'Academie Royale de Belgique, Classe des Sciences, series 2, 7, 1-462.

Vega, F.J., Nyborg, T., Fraaije, R.H.B., Espinosa, B., 2007, Paleocene decapod Crustacea from the Rancho Nuevo Formation (Parras BasinDifunta Group), Northeastern Mexico: Journal of Paleontology, 81, 6, 1442-1451.

Von Meyer, H., 1840, Briefliche Mittheilungen. Neues Jahrbuch für Mineralogie, Geognosie, Geologie, und Petrefaktenkinde, 1840, 576-587.

Young, K., 1963, Upper Cretaceous Ammonites from the Gulf Coast of the United States: Texas, The University of Texas, Bureau of Economic Geology, Publication 6304, 373 p.

Young, K., Marks, E., 1952, Zonation of Upper Cretaceous Austin Chalk and Burditt Marl, Williamson County, Texas: Bulletin of the American Association of Petroleum Geologists, 36, 477-488.

Young, K., Woodruff, C.M., Jr., 1985, Austin Chalk in its Type Area Stratigraphy and Structure: Austin, Texas, Austin Geological Society, Guidebook, 7, 88 p.

Manuscript received: September 25, 2012.

Corrected manuscript received: October 21, 2012.

Manuscript accepted: October 27, 2012. 